\title{
SULUH
}

JURNAL BIMBINGAN DAN KONSELING

http://journal.umpalangkaraya.ac.id/index.php/suluh

\section{ANALISIS ASPEK-ASPEK YANG MEMPENGARUHI HARGA DIRI PESERTA DIDIK}

\section{Analysis Of Aspects That Affect The Self-Price Of Students}

\section{'Winoto, ${ }^{2}$ Andi Riswandi Buana Putra}

IUniversitas Muhammadiyah Palangkaraya, Jekan Raya, Palangka Raya, Kalimantan Tengah, Indonesia

2 Universitas Muhammadiyah Palangkaraya, Jekan Raya, Palangka Raya, Kalimantan Tengah, Indonesia

\section{ARTIKEL INFO}

Diterima

Juni 2018

Dipublikasi

Agustus 2018

*E-mail:

andironaldo@gmail.com

\begin{abstract}
Tujuan dalam penelitian ini adalah: menganalisis aspek-aspek y ang mempengaruhi harga diri peserta didik di SMP I Marikit. Populasi dalam penelitian ini berjumlah 254 orang peserta didik. Jumlah sampel penelitian terdiri dari 63 orang peserta didik. Pengambilan sampel ditentukan dengan teknik random sampling. Teknik pengumpulan data menggunakan observasi, dan skala aspek-aspek yang mempengaruhi harga diri, teknik analisis data menggunakan rumus persentase.

Hasil penelitian menunjukan bahwa harga diri peserta didik di SMP I Marikit cenderung rendah. Adapun aspek-aspek yang mempengaruhi harga diri peserta didik tersebut rendah, yaitu: I) Aspek perasaan bergarga, (kategori rendah yaitu 5I\%); 2) Aspek perasaan mampu (kategori sedang yaitu 57\%); dan 3) Perasaan diterima (kategori rendah yaitu 39\%). Berdasarkan hasil analisis aspek harga diri yang dimiliki peserta didik di SMP I Marikit cenderung rendah dipengaruhi oleh aspek perasaan berharga dan aspek perasaan diterima.
\end{abstract}

ABSTRAK

Kata Kunci: Aspek Harga Diri.

\section{ABSTRACT}

The objectives in this study are: analyzing the aspects that affect the self-esteem of students in Marikit Middle School I. The population in this study amounted to 254 students. The total sample consisted of 63 students. Sampling is determined by random sampling technique. Data collection techniques use observation, and scale aspects that affect self-esteem, data analysis techniques using the percentage formula.The results of the study show that the self-esteem of students in Marikit Middle School tends to be low. The aspects that affect students' self-esteem are low, namely: I) Feelings of quality aspects, (low category that is $5 / \%$ ); 2) Aspects of feeling capable (medium category ie 57\%); and 3) Feelings accepted (low category that is 39\%). Based on the results of the analysis of aspects of self-esteem possessed by students in I Marikit Middle School tend to be low influenced by aspects of feelings of worth and aspects of feeling accepted.

Keywords: Self-Esteem Aspects 
Jurnal Bimbingan dan Konseling

\section{PENDAHULUAN}

Masa remaja adalah masa peralihan dari tahap kanak-kanak yang perlahan mulai ditinggalkan menuju ke tahap dewasa yang belum dijalani. Banyak masalah yang akan dihadapi, baik dengan dirinya sendiri maupun lingkungan sekitarnya. Berdasarkan hasil obaservasi pada bulan November 2016 di SMP IMarikit, terdapat peserta didik yang memiliki harga diri (Self esteem) yang cenderung rendah. Hal ini ditandai dengan peserta didik yang tidak dapat mengontrol tindakan-tindakannya, terdapat peserta didik yang tidak dapat mengekspresikan diri dengan tepat, terdapat peserta didik yang tidak dapat menerima saran dan kritik dari teman, takut terhadap tugas-tugas baru yang diberikan oleh guru, dan perasaan kurang diterima oleh teman.

Melihat fenomena dikalangan peserta didik. Bagaimana fungsi pendidikan nasional bisa tercapai jika remaja mengalami berbagai masalah, khususnya masalah harga diri?. Self esteem berhubungan dengan sikap dan perilaku seseorang. Perilaku peserta didik dapat mencerminkan Self esteem nya. Orang lain dapat mengetahui dan mengukur seperti apa peserta didik menilai dan menghargai dirinya sendiri apakah orang tersebut memiliki Self esteem yang tinggi atau Self esteem yang rendah. Self esteem atau biasa disebut dengan harga diri mencakup perasaan seperti apakah peserta didik dapat menerima keberhasilan atau kegagalan. Seberapa banyak usaha yang yang dia lakukan, apakah kegagalannya akan menyakitkan atau tidak, dan apakah peserta didik 3itu akan lebih mampu sebagai akibat dari pengalaman-pengalaman yang dialaminya. Dariyo (2007:205) mengemukakan Self esteem ialah suatu kemampuan seseorang untuk dapat melakukan penghargaan terhadap diri sendiri. Schultz (Resti, 2016:4) menjelaskan bahwa untuk memiliki perasaan harga diri yang sejati, peserta didik harus mengetahui diri dengan baik dan mampu menilai secara objektif kebaikan dan kelemahan dirinya.

Pada masa ini seseorang belajar mengenali dan mengembangkan seluruh aspek dalam dirinya, baik aspek fisik, psikologis, sosial dan perilakunya secara keseluruhan. Perilaku seseorang dipengaruhi oleh nilainilai yang dimilikinya. Individu yang menanamkan nilai-nilai positif pada dirinya akan berperilaku dan memiliki sifat yang positif pula. Remaja yang memiliki nilai positif terhadap dirinya akan mampu memilah dan memilih perilaku yang mana yang pantas dan tidak pantas dia lakukan. Penilaian yang positif terhadap dirinya tentunya akan dapat menghargai dirinya sendiri dan lingkungannya.

\section{METODE PENELITIAN}

Penelitian ini menggunakan pendekatan kuantitatif karena data yang diperoleh diwujudkan dalam bentuk angka-angka, grafik, atau diagram yang kemudian dianalisis dengan menggunakan rumus-rumus statistika. Data dan informasi yang ingin diperoleh dari lapangan untuk kemudian dideskripsikan adalah tentang aspek-aspek yang mempengaruhi aspek-aspek harga diri peserta didik.

\section{HASIL DAN PEMBAHASAN}

Perasaan berharga yang dimiliki peserta didik cenderung rendah yaitu $51 \%$. Perasaan berharga merupakan aspek harga diri yang semestinya dimiliki oleh peserta didik. Jika peserta didik tidak memiliki perasaan berharga peserta didik cenderung memiliki harga diri yang rendah dan bisa berdampak pada depresi. Hal ini sejalan dengan pendapat Davison \& Neale (Khan, 2012:144) Depresi merupakan suatu keadaan emosi yang ditandai dengan kesedihan dan penderitaan yang mendalam, perasaan tidak berharga dan bersalah, menarik diri dari orang lain, kehilangan selera makan, tidur, bahkan hasrat seksual atau kehilangan minat dan kesenangan 
Jurnal Bimbingan dan Konseling

dalam melakukan kegiatan yang biasanya menyenangkan.

Harga diri positif harga diri adalah perasaan bahwa dirinya penting dan efektif serta melibatkan pribadi yang sadar akan dirinya (Resty, 2016:9). Hasil penelitian ini sejalan dengan pendapat Burns (Resty, 2016:9) yang menjelaskan bahwa individu yang memiliki harga diri tinggi tidak bergantung pada orang lain, mampu menerima kegagalan, mampu membela diri jika mendapat umpan negatif dari orang lain, mampu melindungi diri dari evaluasi negatif kelompok sosialnya.

Menurut Kreitner and Kinicki (Nirmalasari \& Masusan, 2014:19) adalah sebagai berikut: Self esteem is a belief about one's self worth based on an overall selfevaluation. Self esteem is measured by having survey respondents indicate their agreement or disagreement with both positive and negative statement. (Self esteem dipercaya sebagai perasaan berharga seseorang berdasarkan evaluasi diri secara keseluruhan

\section{KESIMPULAN}

Berdasarkan analisis yang telah dilakukan, harga diri peserta didik di SMP I Marikit cenderung rendah. Adapun aspekaspek yang mempengaruhi harga diri peserta didik tersebut rendah, yaitu: I) Aspek perasaan bergarga, (kategori rendah yaitu $51 \%$; 2) Aspek perasaan mampu (kategori sedang yaitu 57\%); dan 3) Perasaan diterima (kategori rendah yaitu 39\%). Berdasarkanhasil analisis aspek harga diri yang dimiliki peserta didik di SMP I Marikit cenderung rendah dipengaruhi oleh aspek perasaan berharga dan aspek perasaan diterima

\section{DAFTAR PUSTAKA}

Dariyo, A. 2007. Psikologi Perkembangan Anak Tiga Tahun Pertama. Bandung: PT Refika Aditama.

Khan, Rosa Imani. 20I2. Perilaku Asertif, Harga Diri dan Kecenderungan Depresi Persona, Jurnal Psikologi Indonesia
September 2012, Vol. I, No. 2, hal I43154.

Nirmalasari, Leli \& Masusan, Khairatu. 2014. Self esteem, Gender Dan Prestasi Kerja (Study Pada Penyiar Radio Di Kota Bandung). SMART - Study \& Management Research. Vol XI, No.2 2014 . ISSN : 1693-4474.

Resty, Gharnish Tiara. 2016. Pengaruh Penerimaan Diri Terhadap Harga Diri Remaja Di Panti Asuhan Yatim Putri Aisyayah Yogyakarta. Jurnal Bimbingan dan Konseling Edisi I Tahun ke-5 2016 